\title{
Risks and Challenges in Public-Private Partnership Projects in Nigeria: A Case Study of the Concession of Murtala Mohammed Airport 2 Terminal (Lagos) to Bi- Courtney Nigeria Ltd.
}

\author{
Sunday Bontur Lugard*
}

\begin{abstract}
Public-private partnership (PPP) has gained global recognition as the key vehicle for the provision of necessary public projects due to the continual inability of governments to fund infrastructural needs of their people - Nigeria is not different as the governments at national and sub-national levels have adopted this model of infrastructural development as a means of addressing this challenge. The Federal government of Nigeria has also keyed into the opportunity of exploiting the financial muscle and management capabilities/expertise of the private sector to the PPP as a platform for the funding and execution of public projects, especially commercial infrastructure like roads, ports, airports, rail system, and public services in the area of healthcare. It was on this premise that the federal government, through the Federal Aviation Authority of Nigeria (FAAN), entered into concession agreement over the building and operations of MM2 airport with Bi-Courtney Aviation Services Ltd, which agreement has been the subject of disputes that have not been fully addressed yet. The goal of this research is to espouse the continuous use of PPP as a medium for the provision of critical infrastructure to the Nigerian populace, while not being oblivious of the need to ameliorate the business environment in the country through the rejigging of the legal and regulatory framework in order to guarantee transparent transactions through public disclosures, timely disputes resolutions framework, among others.
\end{abstract}

\section{Introduction}

The World Bank, et al, define public-private partnership (PPP) as "[a] long-term contract between a private party and a government entity, for providing a public asset or service, in which the private party bears significant risk and management responsibility, and remuneration is linked to performance." Piet de Vries considers PPP as an arrangement that "relates

* Sunday Lugard Bontur, Ph.D; Jus Associates (Legal Practitioners) Abuja, and Department of International Law and Jurisprudence, University of Jos, Nigeria; lugards@unijos.edu.ng.

1 The World Bank, Asian Development Bank, and Inter-American Development Bank, "Public-Private Partnership Reference Guide", version 2.0 (2014) <http://documents.worldbank.org/curated/en/ 600511468336720455/pdf/903840PPP0Refe0Box385311B000PUBLIC0.pdf > accessed 5 June 2019. 
to risk transferring and long-term cooperation between the State and a private institution to realize a public facility and/or service." 2 This usually entails the public sector's exploitation of "private sector skills" to make available facilities (in the form of tangible projects or services) that the market would have less incentives to construct. ${ }^{3}$ The underlying purpose or justification of any PPP project or arrangement is the provision of infrastructure or services that is usually the responsibility of government or other public institutions. The private sector financing and project management capabilities and organizational culture ${ }^{4}$ are exploited for public good in PPP projects, even though it opens up the private firm to enormous risks.

Historically, informal exploitation of private resources for public benefit is as old as recorded history can recount. ${ }^{5}$ Clear examples can be drawn from the ancient Greek city-state of Athens where, for example, in the $4^{\text {th }}$ Century BC, private contributors pooled together resources for the purpose of building public monuments, hosting of public festivals, among others $^{6}$. In Roman Empire also, private citizens collaborated with the army to build infrastructure in the prosecution of Roman expansionist agenda in Europe centuries later. ${ }^{7}$ This approach was used in the USA and France which enabled the setting up and running of the Philadelphia University in the $18^{\text {th }}$ century in US and the construction of the metro-line in Paris, France respectively. ${ }^{8}$

These early models of PPP appear to differ significantly from the modern day character of the concept. In the above examples, there are no indications of an agreement based on concession of the public infrastructure, management, operation and transfer as a key drive towards recouping private financial and expertise exposure. These kinds of private interventions may equally be considered as corporate social responsibility as the element of concession or possession of the public asset with a view to recovery of private financial exposure is not disclosed. Under such a legal construction, the partners share risk, reward, and responsibility for a shared investment. ${ }^{9}$

In Nigeria, the benefits of this model of infrastructure or social service provision got legal backing in 2005 when the Infrastructure Concession Regulatory Commission (Esta-

2 de Vries, P, "The Modern Public-Private Demarcation: History and Trends in PPP" in de Vries, P and Yehouse, E.B, The Routledge Companion to Public-Private Partnerships (Routledge, New York, 2013) 9.

3 Ibid.

4 Verger, A and Moschetti, M, "Public-Private Partnerships In Education: Exploring Different Models and Policy Options" (2016) <http://s3.amazonaws.com/inee-assets/resources/OSF-INEE_PPP-roun dtable_Framing-paper_Verger-Moschetti_ePPPs_(1).pdf> accessed 6 June 2019.

5 Witters, L, et al, "The Role of Public-Private Partnerships in Driving Innovation" in Dutta, S (ed.), The Role of Public-Private Partnerships in 81 Driving Innovation 2012: Stronger Innovation Linkages for Global Growth (2012) $81<$ https://www.globalinnovationindex.org/userfiles/file/GII-2012 -Report.pdf> accessed 5 June 2019.

6 Ibid.

7 Ibid.

8 Ibid.

9 Ibid. 
blishment, Etc) Act ${ }^{10}$ (ICRC Act) was enacted "to regulate Public Private Partnership (PPP) endeavours of the Federal government aimed at addressing Nigeria's physical infrastructure deficit which hampers economic development." 11 Some state governments like Lagos and Ekiti States, have also enacted similar legislations which have enabled them exploit the benefits of such arrangement for infrastructural developments in their states, key among which is the Lekki-Epe Express road concessioned to Lagos Concession Company just like the concession model adopted by the federal government in key sectors of the economy which lack basic infrastructure.

PPP financing and execution of public projects come with a myriad of advantages in the pursuit of infrastructural development. They provide public infrastructure and services where there is low coverage of an area, low quality or low reliability in terms of the infrastructure or services required by the public. This may be motivated by the insufficiency of public funds for the outright provision of the facility or services by the government, poor planning and project selection, insufficiency or ineffective delivery or inadequate maintenance. In addition, PPP helps by providing additional sources of funding and finance, private sector analysis and innovation, sector experience and incentives, and long term investment perspective. The major public sector benefit of this sort of transaction is in increased fiscal resources, and improved public sector capacity and governance. ${ }^{12}$

\section{Types of PPP}

The nature or type of PPP adopted regarding a specific project is shaped by a couple of considerations relating to: the nature of public asset to be conceded to the private party determines its taxonomy - the asset could be new ("greenfield") or an old one that requires refurbishment ("brownfield"). ${ }^{13}$ Similarly, the form of the function the private party is required to perform determines the nature or type of the PPP type to be adopted. This may be a function of the kind of asset and services involved. This may involve designing, building or rehabilitating the asset or provision of the services required - the private party is mostly required to provide the full funding or part-funding of the necessary capital expenditure for the project ${ }^{14}$. This usually extends to maintaining and operating the asset. How the private

10 Act of 2005.

11 ICRC, "History" < http://www.icrc.gov.ng/about-icrc/> accessed 21 June 2019.

12 Witters, L, et al, (note 5) at 31 (table 1.3)

13 World Bank, "Public-Private Partnerships Reference Guide: Version 2.0" (2014) $18<$ http://api.nin g.com/files/Iumatxx-0jz3owSB05xZDkmWIE7GTVYA3cXwt4K4s3Uy0NtPPRgPWYO1lLrWaT UqybQeTXIeuSYUxbPFWlysuyNI5rL6b2Ms/PPPReferenceGuidev 02Web.pdf $>$ accessed 17 September 2019.

14 Ibid. 
party will be paid. ${ }^{15}$ This may be in the form of collecting fees from users of the asset or the payment may come from government, or both. ${ }^{16}$

Juan Rodriguez identifies ten forms of PPPs ${ }^{17}$ which basically include the traditional PPP, built-operate-transfer, concession, lease, among others. In the same vein, PPPs have been regarded as chiefly comprising of models including: outsourcing and partnering; performance-based contracting; design, build, finance and operate (or build operate transfer) contracts; and sometimes, concessions ${ }^{18}$, the most common models in operation in Nigeria include concession; build, operate and transfer; among others. Whatever form of PPP adopted, it comes with a number of risks to either or both parties to the transaction: public sector or the private enterprise. This takes various forms.

\section{Risk Level in PPP-Financed Infrastructural Development Model in Nigeria}

Wang, et al, classify risks in PPP projects into internal and external risks ${ }^{19}$. While internal risks are common with every project such as design risk, construction risk, operation and maintenance risks among others, external risks are negative uncertainties arising due to project's interaction with the environment. Examples of external risks in PPP projects include regulatory risk, concession risk, currency or foreign exchange risk, political or social uncertainties, reputational risk, among others ${ }^{20}$. According to Liu, et $\mathrm{al}^{21}$, although external risks abound in most projects regardless of where they are being delivered, the impacts of such external uncertainties are greater in emerging markets PPP projects. For example, a country like Nigeria which is an emerging economy and currently at the lower level of the personal finance initiatives (PFI)/PPP maturity model has been bedevilled by a lot of country-related

15 Ibid.

16 Ibid at 19.

17 Traditional PPP, operation and maintenance, design-build, design-build-operate, design-build-finance-operate, build-transfer-operate, build-own-operate-transfer, build-own-operate, lease, and concession. See Rodriguez, J, "Public-Private Partnership Models" (2019) < https://www.thebalanc esmb.com/public-private-partnership-types-845098> accessed 12 September 2019.

18 Onuobia, F, Okoro, OJ, and Mimiko, B, "Nigeria" in Werneck, B and Saadi, M, ed., The PublicPrivate Partnership Law Review, 3rd ed. (London: Law Business Research Ltd, 2017) 157.

19 Wang, S.Q., Dulaimi, M.F. and Aguria, M.Y. (2004), "Risk management framework for construction projects in developing countries", Construction Management and Economics, Vol. 22 No. 3, pp. 237-252.

20 Akintoye, A., Beck, M. and Kumaraswamy, M. (Eds) (2015), Public Private Partnerships: A Global Review, Routledge, Abingdon, Oxon \& New York, NY; Oyedele, L. (2013), “Avoiding performance failure payment deductions in PFI/PPP projects: model of critical success factors", Journal of Performance of Constructed Facilities, Vol. 27 No. 3, pp. 283-294.

21 Liu, T., Wang, Y. and Wilkinson, S. (2016), "Identifying critical factors affecting the effectiveness and efficiency of tendering processes in public - private partnerships (PPPs): a comparative analysis of Australia and China", International Journal of Project Management, Vol. 34 No. 4, pp. 701-716. 
risk factors ${ }^{22}$ - which are chiefly external. That being the case, the concern of this work shall be with the external risk factors generally, and in the MM2 airport concession to Bi-Courtney Aviation Services Limited in particular.

In recognition of the pervasive extent of the external risks and challenges associated with PPP projects in Nigeria generally, the regulatory agency or the contracting authority, Infrastructure Concession Regulatory Commission (ICRC), record shows that about 50 public infrastructure have been concessioned (based mainly on the build, operate and transfer model of PPP) to the private sector from its inception till date. ${ }^{23}$ Of this number, 24 (about half) of the projects are being implemented but the contracts are undergoing review based on operators' challenges with support infrastructure like access roads, while other challenges like host community uprising, security issues, among others, are prevalent. One of the projects "expired", 5 of them have had their contracts terminated, 11 are undergoing smooth implementation, one has been suspended, 6 of them are being implemented but are subjects of dispute either in courts or undergoing negotiated settlement, and two of them have had their "implementation stalled".

The above statistics make a huge statement on the enormous level of risk that a prospective investor would be exposed to in relation to PPP project with the Federal Government of Nigeria, hence the need to undertake due diligence before having "boots on the ground". Only about $50 \%$ of the projects have either been completed and the contract discharged or they are ongoing projects without issues. Key among the challenges or risks associated with PPP projects in the country is political risk. This kind of risk is typified in the case of Maevis Ltd. v. SITA Telecommunications Nig. Ltd. ${ }^{24}$ In this case, the Federal High Court upheld the right of the private party under the PPP contract to enforce its rights without any third party interference. The plaintiff under a PPP contract with with the Federal Airports Authority of Nigeria (FAAN) in 2007 agreed to provide services to four airports in Nigeria. Sometime in 2010, some terms of the agreement became subject of dispute, consequent upon which the plaintiff instituted this suit, but the court referred parties to arbitration as agreed in their PPP contract document. The Court further ordered parties to maintain the status quo pending the determination of the matter by the arbitration panel. However, in 2011, FAAN purportedly terminated the contract with the plaintiff and went on to enter into another contract regarding the provision of the same services with Sita Telecommunications Nigeria Ltd and Société Internationale de Télécommunications Aéronautiques (SITA) (the defendants). The defendants despite being informed of the pending suit ad order of court chose to enter into a subsequent contract with FAAN. The court held that

22 Osei-Kyei, R. and Chan, A.P. (2015), "Review of studies on the critical success factors for publicprivate partnership (PPP) projects from 1990 to 2013”, International Journal of Project Management, Vol. 33 No. 6, pp. 1335-1346.

23 ICRC, "Projects under Implementation (Post-Contract)" $<$ http://www.icrc.gov.ng/projects/projects -under-icrcs-custody/> accessed 21 June 2019.

24 (2013) 10 CLRN 124. 
the defendants acted unlawfully by interfering with the contract between Maevis Ltd and FAAN, even when it had knowledge of the pending litigation.

The concession and operations of MM2 by Bi-Courtney Aviation Services Limited, just like the case of Maevis Ltd., is not without its own challenges which border on political risk.

\section{The Concession and Operations of Mm2 To Bi-Courtney Nigeria Limited}

The level of infrastructural deficit in Nigeria makes PPP model of infrastructural development a viable option to the government, especially the central government. It is estimated Nigeria needs to invest a minimum of $\$ 15$ billion dollars annually to meet its infrastructure challenge. ${ }^{25}$ This is not currently feasible as the total federal government's budgetary allocation for capital expenditure for the financial year 2019, for instance, is N2.93 trillion (\$8.1 billion). ${ }^{26}$ This would ordinarily leave a funding deficit of about $\$ 7$ billion, but using the immediately preceding financial year's budget performance of about $69 \%$, it is obvious that the budgeted capital expenditure may come down to about $\$ 5.6$ billion. This is about a mere third of the required amount of capital expenditure for public infrastructure till the year 2040. This sort of funding constraint makes the need to consider PPP project funding model a viable option for the provision of commercial infrastructure in specific sectors like transport (roads construction, construction of standard gauge rail lines, airports and aviation facilities provision, ports infrastructure), public water supply, electric power generation and supply, among others. Asides the finding challenge from public coffers, other impediments, including corruption, poor planning and coordination, politics and personal gain interfering with the selection/procurement process, among other likely challenges.

This state of affairs informed the government's decision to engage a private enterprise, Bi-Courtney Aviation Services to build, operate and transfer the Murtala Mohammed Airport 2 (MM2) and operate for a an initially agreed period of 12 years, in order to recoup their financial exposure and transfer possession and management off this facility back to the federal government.

While the concessionaire, Bi-Courtney Nigeria Limited, claims the concession to design, develop, finance, construct, complete, test, commission, operate, manage, maintain and

25 Oxford Economics, estimates that Nigeria's cumulative infrastructure spending need (investment need scenario) between 2016 and 2040 is about US\$878 billion while the expected spending would be about US\$657 billion, leaving a gap of over US\$200 billion. See Global Infrastructure Outlook, Infrastructure investment needs, 50 countries, 7 sectors to 2040, Oxford Economics, July 2017, 8 quoted in Julia Bello-Schünemann and Alex Porter, "Building the future Infrastructure in Nigeria until 2040" $<$ https://issafrica.s3.amazonaws.com/site/uploads/war-21.pdf $>$ accessed 30 July 2019.

26 Udo Udoma, "Breakdown of 2019 FGN Approved Budget: Public Presentation of the 2019 Budget of Continuity" (2019) < https://www.budgetoffice.gov.ng/index.php/breakdown-of-2019-fgn-appr oved-budget/breakdown-of-2019-fgn-approved-budget/download> accessed 30 July 2019. 
transfer of the MMA2 Terminal (Lagos) is for a period of 36 years $^{27}$, the Federal Government, represented by the Infrastructure Concession Regulatory Agency and Federal Airport Authority of Nigeria (FAAN), claims it was billed to last for 12 years beginning from 2006-2018. ${ }^{28}$ Interestingly, the government regulatory agency, ICRC, admits that the project is "[u]nder Implementation though faced with challenges" because even though the contract was initially billed to last for 12 years, "[h]owever, Operator obtained a ministerial approval for extension to 36 years which is being contested by FAAN". ${ }^{29}$

The above situation is an indication of political risk in associated with PPP projects in the country generally, and poor dispute resolution structure and lack of transparency in dealings of this nature, as initially noted in the case of Maevis Ltd. v. SITA Telecommunications Nig. $L t d^{30}$. The extension of the tenure of the project was done by the previous government in questionable circumstances, as due process - procuring the approval of the Federal Executive Council was not done by the private party to the agreement. The issue however is whether the Minister has the power to grant the extension claimed by the concessionaire as it is clearly stipulated in section 2(2) of the Infrastructure Concession Regulatory Commission (Establishment, Etc) Act $^{31}$ that it is only the Federal Executive Council that is empowered to grant such approval.

\section{Risks and Challenges Associated with the Concession of MM2 to Bi-Courtney Aviation Services Limited}

Usually, there are various models of PPP which are determined depending on both the nature of the responsibilities of private partners and the ownership of the asset. ${ }^{32}$ PPP models of delivery are exposed to risks, but a successful PPP programme will identify, price and transfer risk from the public sector to the private sector. ${ }^{33}$ even though the risks are not totally resident with or transferred to the private party. An example of this can be found in the PF2 arrangement in the United Kingdom (until its recent abolition) which required the public party to take responsibility concerning any increment sin insurance, unforeseeable increase in the cost of the project due to the default of the public party or not, purchase of

27 Murtala Mohammed Airport Two, "Our History" <https://www.mma2.com.ng/corporate-informati on/our-history/> accessed 2 June 2019.

28 Infrastructure Concession Regulatory Commission, "Projects Under Implementation (Postcontract)"

$<$ http://www.icrc.gov.ng/projects/projects-under-icrcs-custody/> accessed 2 June 2019.

29 Ibid.

30 Supra.

31 Act of 2005.

32 Lemma, A, "Literature Review: Evaluating the Costs and Benefits of Centralised PPP Units" (2013) p. $9<$ https://assets.publishing.service.gov.uk/media/57a08a49e5274a31e0000510/Evaluati ng_the_Costs_and_Benefits_of_Centralised_PPP_Units_24.pdf $>$ accessed 16 September 2019.

33 Ibid. 
minority shares in the Special Purpose Vehicle (SPV) that would execute the contract $^{34}$ in order to secure government buy-in and cooperation.

Solomon O. Babatunde and Akintayo Opawole identified nine critical success factor in public-private partnerships as: competitive procurement process, thorough and realistic assessment of the cost and benefits, favorable framework, appropriate risk allocation and risk sharing, government involvement by providing a guarantee, political support, stable macroeconomic condition, sound economic policy and availability of suitable financial market. ${ }^{35}$ It is the non-availability of the factors identified above that constitute some of the key challenges in the PPP contract (FAAN and Bi-Courtney Aviation Services Limited over the construction of MM2 Airport terminal) that is the subject of this review. These challenges include: political risk, inefficient dispute resolution framework, corruption, legal and regulatory challenges, contract renegotiation risk, and lack of transparency and disclosure policy in the contract award and execution.

Political Risk. Policy instability, public governance inefficiency and poor work attitude, among others constitute a political risk that business must consider in entering into a PPP agreement with governments. ne of the key impediments to public governance in developing countries generally and Nigeria in particular is risk associated with political governance. The United Nations Economic Commission for Europe (UNECE) ${ }^{36}$ realizing the place of governance as a key driver of a successful and sustainable PPP framework and enforcement system define it to include six key areas:

a. Efficiency. This entails minimizing resource waste, corrupt practices, delay and minimal intergenerational burden transfer.

b. Accountability. The level of political actors' responsibility to society for decisions as their official representatives.

c. Transparency. This mainstreams clarity and openness in decision making.

d. Decency. Designing and enforcing decisions without causing grievance to the people.

e. Fairness. Non-discrimination in the application of rules.

f. Participation. Stakeholder involvement in the decision making process and implementation structure. ${ }^{37}$

In Bi-Courtney's concession agreement with FAAN, the public party has been accused of manifold "breaches" of the terms of the agreement. This resulted in the waste of financial resources and time that the private party would have deplored or used profitably. The MM2

34 Richards, M, et al, "United Kingdom" in Sombra, TL and Moreira TF (ed.), The Public-Private Partnership Law Review, 5th ed. (London, Law Business Research Ltd., 2019) 255-6.

35 Babatunde, SO, and Opawole, A, "Critical Success Factors in Public-Private Partnership (PPP) on Infrastructure Delivery in Nigeria" (2012) 10(3) Journal of Facilities Management $212<$ www.em eraldinsight.com/1472-5967.htm> accessed on 17 September 2019.

36 United Nations Economic Commission for Europe (UNECE), "Guidebook in Promoting Good Governance in Public-Private Partnerships" (2008) 13-14<https://www.unece.org/fileadmin/DAM/ce ci/publications/ppp.pdf> accessed 31 July 2019.

37 Ibid. 
concession has been a subject of litigations and endless "negotiations" between the government and the private part to the contract - Bi-courtney Aviation Services Limited due to politically-induced uncertainties. The Supreme Court's decision in Bi-Courtney Aviation Services Ltd. v. Attorney General of the Federation \& $A M C O N^{38}$ vividly portrays the fact that the government, represented by FAAN, was guilty of several breaches of the agreement and liable to pay compensation to the private party.

Corruption. The parties to this PPP projects have both been accused of corrupt practices aimed at altering the nature and the extent of the terms of the contract. For instance, the chairman of the private party to the contract has been alleged to have offered bribes to government officials, particularly the former Attorney General of the Federation, Andoakaa, SAN, in order for his office to undertake an inefficient defence of the case against the government with a view to giving the private party a good day in court. ${ }^{39}$ When government officials who are the representatives or the guardians of the public interest are easily compromised, this leaves much to be desired as that would make the terrain unpredictable and subject business that are ready to cooperate to pay bribes that translate into higher cost. This is asides the unethical implications and repetitional risk a compromising company is exposed to. The government has to consciously review the welfare package of their personnel asides training them to gain the right skills on how to best negotiate deals that represent the interest of its people.

Inefficient dispute settlement mechanism. The PPP project has been the subject of litigation and endless "renegotiations" which have brought with it uncertainties and loss of precious time and financial resources. The concession agreement has been a subject of endless disputes and the settlement mechanism has been anything but efficient. It has been reported that the federal government agency representative in the concession agreement, FAAN, consistently breached terms of the agreement which resulted in the call for a "Coordinating Committee" based on the agreement to resolve the issues. This was honoured by the FAAN and the committee was set up to resolve the issues concerning the failure of the government to do its own part of the bargain as stipulated in the agreement. ${ }^{40}$ the continuous breaches of the agreement despite the resolution of the "Coordinating Committee" led to the institution of legal proceedings by Bi-Courtney in the Federal High Court ${ }^{41}$. The Court of first instance upheld the claims of the concessionaire that the Federal Government should render account of all monies collected from their other airports asides MM2 as mu-

38 Suit No. SC.770/2014 - decision of the Supreme Court delivered on the 5th April 2019.

39 Sahara Reporter, "How Aondoakaa sold Murtala Mohammed Airport to Wale Babalakin's BiCourtney" (24th September, 2009) <http://saharareporters.com/2009/09/24/how-aondoakaa-sold-m urtala-mohammed-airport-wale-babalakin $\%$ E2\%80\%99s-bi-courtney> accessed 17 September 2019.

40 Akintunde, A, "The Supreme Court Declares AMCON's Application to Appeal as an Interested Party, Incompetent" (Thisday Newspapers, 7 May 2019) <https://issuu.com/thisdaylive/docs/1905 07162611-53ace9046e754baea3f30ed99153f659> accessed on 10 September 2019.

41 In Suit No.: FHC/ABJ/50/2009. 
tually agreed by parties. The government still didn't botch after the judgement of the court. This led the concessionaire to unilaterally compute it at about N132.5 billion based on a subsequent order granted by the Federal High Court consequent upon the failure of the government to comply with the initial judgement. A government agency, Assets Management Corporation of Nigeria (AMCON) sought in vain a court leave to appeal the judgement of the court of first instance. The Supreme Court in May 2019 held that the application to be joined as an interested party by AMCON was incompetent not having been filed at the court of first instance but the Court of Appeal. ${ }^{42}$ The implication of this judgement is that the federal government is liable to account to the concessionaire as held by the court of first instance.

In all, this suit took ten years to be determined by the Supreme Court. This is a long period of time for settlement of issues relating to business. Secondly, the parties have further commenced renegotiation of the terms of the agreement, while the key dispute regarding the period of concession is still unresolved. This does not augur well for business as the certainty of rules and quick determination or settlement of disputes are at the centre of issues business wants to be clear about before entering into contract in order to avert negative financial exposure.

Lack of Legal and Policy Requirements on Transparency and Disclosure. The legal and regulatory frameworks for PPP in Nigeria do not mainstream the duty to disclose information concerning the design and execution, and the terms and contents of the agreement. For instance, section 4(a) of the Public Procurement $\mathrm{Act}^{43}$ merely provides in general terms that the goal of the Bureau of Public Procurement is to harmonise public policies and practices regarding public procurement (including PPP projects) in order to secure "probity", "accountability", and "transparency" of the process. This sort of provision does not impose any specific responsibility on the public representatives regarding disclosing the contents of contracts reached with public parties - wherein the details regarding mode of payment for the projects, tenure, among others are disclosed. This being the case, the private party and the public representative are the stakeholders that have access to the agreement while the public and other stakeholders like the NGOs can merely conjure the responsibilities of parties under the agreement. In realisation of the need to enhance transparency and disclosure in its operations, the ICRC states that "The ICRC in collaboration with the World Bank Institute (WBI) seeks to ensure transparency in PPP contract implementation in Nigeria in line with global best practices" with a view to making easily available to the public "non-confidential" information relating to PPP contracts in the country. This though a laudable initiative, the website where ICRC claims to have made accessible to the public information re- 
garding the project in issue has been inaccessible, hence defeating the purpose of such initiative. $^{44}$

Another risk associated with the PPP agreement in issue is contract renegotiation risk the risk of accepting back some costs and risks whenever a government has to renegotiate contract terms with a private partner. ${ }^{45}$ several terms of the agreement, including the tenure, have been renegotiated due to the failure of the government to abide by the tenets of their agreement with the private party. As at the time of writing this paper, the tenure of the agreement is still a subject of renegotiation as both parties claim different tenures, due to outcomes of renegotiation of the agreement. The major challenge associated with renegotiation of terms of the agreement with the government is the imbalance in the negotiation power of the parties. The private party having injected its funds, especially when they were borrowed, isn't left with so much of a choice than to continue with the project so as to minimise the risk of loss of funds.

\section{Lessons from other Jurisdictions}

On disclosure of performance information, while the United Kingdom and India have PPP databases that are placed in the public domain ${ }^{46}$, the same cannot be said of Nigeria where the PPP contracts are not open to public nor the opportunity to make input on such agreement, by key stakeholders. The ICRC claims that it has made available information that are non-confidential on their website for public access. This is intriguing as all that is visible on their website merely indicates the names of the PPP projects they have taken custody of and the level of implementation. This brief information does not include the contract sum, tenor of the agreement, method of recover of private party's financial exposure, and other details that can only be found in the contract document itself. This lack of disclosure is one of the key reasons why PPP projects, particularly the Bi-Courtney and FAAN MM2 agreement is subject to avoidable conflict. While the private party claims an inexplicable extension of the agreement from 12 years to 36 years, FAAN insists the duration of the agreement has been fully spent. Making available the key contract documents like the initial contract document and the claimed extension document would have enabled the public to compare both documents and find the rationale for the extension of the agreement by adding additional 24 years to the initially agreed duration of the agreement. All are mere subjects of conjecture: why the extension? Why a whopping 24 additional years to the initial period? Is it the case that the private party was unable to recoup its investment within the twelve years

44 All attempts spanning several days to access the web page for the contract document between the parties proved abortive. See $<$ http://ppp.icrc.gov.ng/project/128/mma2-terminal $>$ attempted accessed on 16-18 September 2019.

45 Lemma (note 28).

46 ICRC, "Disclosure of Project and Contract Information in Public Private Partnerships in Nigeria Introductory Note" $<$ https://drive.google.com/file/d/0BzaBhwB6XxLWS2JqSGszWEt2Wms/edit> accessed 21 June 2019. 
initially agreed by parties? There are too many questions and the answer would have been found in the contract document and the document extending it. The private party and the former government that extended the contract duration have not shown that there was compliance with due process in giving the extension. This are the sort of circumstances that give room for corrupt and unethical behaviour on the part of decision makers.

Furthermore, Nigeria has lessons to learn from the United Kingdom which has grown in its use of PPP as a medium for efficient provision of infrastructure and services hence enabling the system benefit immensely from funding and management expertise of the private sector. ${ }^{47}$ The United Kingdom, in the 1990s, adopted the Private Finance Initiative (PFI) approach and subsequently PF2 - which further required the public party to purchase some minority shares in the special purpose vehicle (SPV) established to execute the project; take responsibility for increased insurance obligation; government undertaking to shoulder the responsibility for any unforeseen increase in cost of the project beyond what was initially contemplated by parties; among other transferred risks from the private party to the public sector $^{48}$ as a means of mitigating the financial risk and other risks by the private party. This risk sharing approach was questioned for not giving enough value for public money hence its recent termination. This sort of approach is likely to better protect the interest of the private party in Nigeria if cautiously explored by the government. This is because the government does not just play a supervisory role in the execution of the project, but are part owners of this sort of "joint venture" enterprise. This has the potentials of curbing the passive disposition of the government officials who see their role as that of an enabler and not participant.

In the same vein, Nigeria has lessons to learn from a developing country like Lebanon which PPP Law has specific provisions regarding the content of standard from PPP $\operatorname{contract}^{49}$, which are lacking in the Nigerian legal framework. The Law requires that the following be captured by the PPP contract: rights and obligations of partiers, means of financing the project, time frame of the project not exceeding 35 years, revenue from the project - terms of payment, taxes, implementation reports to be submitted to the public entity, risk allocation, guarantees, transfer of project to the public entity on termination of the agreement, dispute resolution ${ }^{50}$, among others. The advantage inherent in this approach is that the key elements of the agreement are necessarily captured in the contract which makes enforcement easier, and breach is easy to identify and not merely conjured by parties. The agreement between FAAN and Bi-Courtney Limited might have contained most of these

47 Richards, M, et al, "United Kingdom" in Sombra, TL and Moreira TF (ed.), The Public-Private Partnership Law Review, 5th ed. (London, Law Business Research Ltd., 2019) 252-273.

48 Ibid.

49 Melki, H, "Lebanon" in Sombra, TL and Moreira TF (ed.), The Public-Private Partnership Law Review, 5th ed. (London, Law Business Research Ltd., 2019) 124-125.

50 Ibid. 
provisions as industry requirement or global best practices, but the non-accessibility of the contract document only feeds assumptions as to its contents.

\section{Recommendations and Conclusion}

Key points on improving the PPP project implementation in Nigeria:

Private entity partners in PPP projects in the country may have to insist on the introduction of stabilization clauses in contract documents in order to mitigate the sponsors' risk in the event of currency value depreciation - this is because some of the sponsors take foreign loans to execute some PPP projects and any devaluation of the local currency increases the risk of debt servicing and repayment. This approach has been used in relation to extractives industries contract with the federal government of Nigeria as a vehicle of risk mitigation.

Similarly, Alternative Dispute Resolution should be made compulsory and the final means of settling disputes between parties within a specified period of time in order to avoid time consuming litigations, and where litigation is considered as a last resort, it should not form the basis for the disruption of the implementation of the PPP contract.

Where the funding of the projects is a loan from a financial institution, some form of performance guarantee should be procured by the government from reliable financial institutions, some foreign lenders require Multilateral Agencies like the World Bank involvement as a guarantee for granting the loan to execute the project. This arrangement would underwrite the political risk inherent in the agreement being investigated.

The challenge of lack of transparency and non-disclose of the contents of contract do not serve public good. The Indian and United Kingdom examples should be adopted. Disclosure requirement may not extend to confidential information for the purpose of protecting the copyrights, industrial designs, patents and similar embodied or disembodied information or other elements that a party of the PPP has proprietary right over, but the nonconfidential one should be consciously made available and easily accessible to members of the public.

Environmental and social risk should be addressed by procuring prior host community buy-in and a rigorous and open EIA process before issuance of permit. Even though social risk was not an issue in this particular project, similar projects have been halted because of community uprisings and interferences. The private entity to the PPP project should undertake serious due diligence using on-the-ground experts in order to avoid loss of revenue or time while undertaking the project.

From the above, it is not in doubt that the huge infrastructural challenge in Nigeria is an opening for investors to joint hands with the governments at national and sub-national levels through PPP to provide the needed infrastructure while still protecting the interests of the public and the private entity as well. The conscious evaluation and redress of concerns relating to the legal and regulatory framework that promote transparency and public disclosure regarding project agreements, political risk mitigation and time-based alternative dis- 
pute settlement mechanism are needed for a better investor confidence and security of investments. 